\title{
Effect of Plant Hormones on Callus Induction from Fruit and Seedling Explants of Chilli Pepper (Capsicum
} annuum L.)

\author{
El Kaaby, Ekhlas Abdulkareem jasim ${ }^{1}$, Al-Ajeel, Saadon. Abdulhadi. ${ }^{2}$ and Al Hattab, Zahra Noori ${ }^{1}$ \\ 1. Department of Genetic Engineering, Biotechnology Center, Ministry of science and Technology, Baghdad 10001, Iraq \\ 2. Department of Biology, Faculty of Education, University of Kufa, An-Najaf 54001, Iraq
}

Received: January 15, 2014 / Accepted: January 17, 2015 / Published: January 30, 2015.

\begin{abstract}
This experiment was conducted to optimize the culture conditions to induce calli from chilli pepper (Capsicum annuum L.) local cultivar. The mature seeds were surface sterilized for one min with $70 \%$ Ethanol followed by 20 min with $(0 \%, 2 \%, 4 \%$ or $6 \%)$ $\mathrm{NaOCl}$ and were germinated on MS medium with $2 \mathrm{mg} / \mathrm{L} \mathrm{GA}_{3}$. Seedlings and mature fruits were used as explants source. The placenta, pericarp, hypocotyls, cotyledonal leaves, shoot tips and roots were cultured on MS media supplemented with Kinetin ( 0.0 $\mathrm{mg} / \mathrm{L}, 0.5 \mathrm{mg} / \mathrm{L}, 1.0 \mathrm{mg} / \mathrm{L}, 2.0 \mathrm{mg} / \mathrm{L})$ and IAA $(0.0 \mathrm{mg} / \mathrm{L}, 1.0 \mathrm{mg} / \mathrm{L}, 2.0 \mathrm{mg} / \mathrm{L})$ in different combinations or NAA or 2,4-D $(0.0 \mathrm{mg} / \mathrm{L}$, $1.0 \mathrm{mg} / \mathrm{L}, 2.0 \mathrm{mg} / \mathrm{L}, 4.0 \mathrm{mg} / \mathrm{L}$ ). Callus fresh weight was recorded after 4 weeks in culture. The results showed that the best sterilizing method was with $70 \%$ Ethanol followed by 20 mints with $(4 \%$ or $6 \%) \mathrm{NaOCl}$, however $6 \% \mathrm{NaOCl}$ reduced seed's viability. Callus was induced from all explants cultured on MS media supplemented with IAA and Kinetin except the placenta and the pericarp. The results showed that the hypocotyls surpass all other explants in the mean callus fresh weight which was $160.58 \mathrm{mg}$ compared with $147.81 \mathrm{mg}, 134.95 \mathrm{mg}$, and $122.33 \mathrm{mg}$ for cotyledonal leaves, shoot tips and roots respectively. Moreover the analysis of the interaction between the growth regulators and the explants showed that $2 \mathrm{mg} / \mathrm{L}$ IAA and Kinetin had significant effect on callus mean fresh weight which was $(309.74,339.14,358.48$, and 284.64) $\mathrm{mg}$ for the shoot tips, cotyledonal leaves, hypocotyls and roots, respectively. On the other hand, $2 \mathrm{mg} / \mathrm{L}$ 2,4-D or NAA was the best concentration for callus induction from the placenta and the pericarp. The pericarp gave a mean fresh weight of $276.90 \mathrm{mg}$ in the presence of 2,4-D compared with $253.60 \mathrm{mg}$ for the placenta. Moreover the pericarps gave significantly higher fresh weight than the placenta with an average of $210.3 \mathrm{mg}$ and $184.9 \mathrm{mg}$ respectively in the presence of $2 \mathrm{mg} / \mathrm{L}$ NAA. In conclusion the best sterilization method of chilli pepper seeds is by $70 \%$ ethanol for one minute followed by $20 \mathrm{~min}$ in $4 \%(\mathrm{NaOCl})$. The best explants for callus induction only is the Hypocotyls grown on MS medium supplemented with $2 \mathrm{mg} / \mathrm{L}$ of IAA and Kinetin under the conditions of the current experiment.
\end{abstract}

Key words: Fresh weight, IAA, NAA, 2,4-D, kinetin, pericarp, root, hypocotyls, cotyledonal leaves, shoot tips.

\section{Introduction}

Chilli pepper (Capsicum annuum L.) is one of the important plants of the family Solanaceae which is grown world widely. Pepper has been used as nutritional and economical [1], industrial [2] and medicinal [3] plant. Therefore many researchers are interested in improving pepper productivity by using biotechnology methods such as tissue culture [4].

Corresponding author: El Kaaby, Ekhlas Abdulkareem jasim., M.S., research field: biotechnology. E-mail: ekhlasjasim@yahoo.com.
There are many factors affecting any plant tissue culture. Growth regulators and the explants which are used to initiate the callus culture may have the highest impact on the success of culture establishment. Several reports showed the effect of hormones in different combinations and different concentrations on callus induction from different pepper varieties. Abundant of callus formed on the cultured cotyledons, hypocotyls and shoot tips when 2, 4-D was used in the initiation medium [5]. Other researchers produced calli from protoplast successfully using combination 
of BAP and NAA in different concentrations [6]. Moreover callusogenesis were induced from anthers of many pepper verities [7]. Moreover an efficient system was established for inducing calli from two Capsicum varieties staring with young leaf, apex, hypocotyls and cotyledons explants by using auxins and cytokinins of different combinations and concentrations [8]. An efficient and reliable In vitro protocol was established for induction and regeneration of calli in varieties of hot calli (Capsicum frutescens L.) var. Nepali and NARC-IV. Early initiation and induction with sustainable calli growth in both varieties was achieved using 2, 4-D [9].

The conditions of all experiments are specific for the variety under investigation. Therefore the main objective of the current study was to test the ability of a wide range of explants of chilli pepper (shoot tips, cotyledons, hypocotyls, roots, placenta and pericarp) to induce calli with sustainable growth under the influence of different growth regulators using a native cultivar of Capsicum annuum $\mathrm{L}$.

\section{Materials and Methods}

This research was conducted at the tissue culture laboratory of Genetic Engineering Department, Food and Biotechnology Center, Ministry of Sciences and Technology during the year 2012-2014. Mature seeds of chilli pepper local cultivar were purchased from local market and used in this experiment.

Seeds were surface sterilized with $70 \%$ Ethanol for one mint. Then they were transferred to Sodium Hypochlorite $(\mathrm{NaOCl})$ of different concentrations $(0.0 \%, 2.0 \%, 4.0 \%$, or $6.0 \%)$ for $20 \mathrm{~min}$ with continuous stirring. The seeds were rinsed three times with sterilized distilled water $5 \mathrm{~min}$ each and cultured on full strength MS [10] supplemented with $2 \mathrm{mg} / \mathrm{L}$ $\mathrm{GA}_{3}, 30 \mathrm{~g}$ Sucrose and $6 \mathrm{~g}$ Agar. Cultured seeds were incubated in the culture room at $25 \pm 2{ }^{\circ} \mathrm{C}, 16 \mathrm{~h}$ light of 1000 Lux intensity and $8 \mathrm{~h}$ darkness. Contamination percentage was recorded after 7 days.

The germinated seeds were used as explants source.
Cotyledonal leaves, Hypocotyls, Shoot tips and Roots were cultured on the germination medium that where supplemented with different combinations of $(0.0$ $\mathrm{mg} / \mathrm{L}, 0.5 \mathrm{mg} / \mathrm{L}, 1.0 \mathrm{mg} / \mathrm{L}, 2.0 \mathrm{mg} / \mathrm{L}$ ) Kinetin and $(0.0 \mathrm{mg} / \mathrm{L}, 1.0 \mathrm{mg} / \mathrm{L}, 2.0 \mathrm{mg} / \mathrm{L})$ IAA. Whereas the Placenta and the Pericarp were cultured on the germination medium that where supplemented with NAA and $2,4-\mathrm{D}$ at concentration $(0.0 \mathrm{mg} / \mathrm{L}, 1.0 \mathrm{mg} / \mathrm{L}$, $2.0 \mathrm{mg} / \mathrm{L}, 4.0 \mathrm{mg} / \mathrm{L}$ ) for each of them with different combinations. The effect of growth regulators on callus fresh were recorded after 4 weeks from culture.

All the experiments were conducted in CRD (Complet Randomized Design) with 10 replications per each treatment. Collected data were analysed using Gen Stat program [11] and the means were compared using L.S.D. (least significant differences) at $0.05 \%$ probability.

\section{Results}

\subsection{Explants Sterilization}

The results of the sterilization experiment (Table 1) showed significant differences among the treatments in the elimination of contamination. Using ethanol alon gave $100 \%$ contamination in the seeds and the pericarp while the placenta showed $61 \%$ contamination. This result was expected because the placenta is protected from the environment by the pericarp and it is the main source of Capsicine which has antibiotic and antifungal activities [12]. Sterilization with Sodium Hypochlorite after Ethanol treatment reduced the contamination. As the concentration of Sodium Hypochlorite was increased the percentage of contamination was decreased. The highest percentage was $87 \%$ for the control treatment followed by $43.11 \%$ for $2.0 \% \mathrm{Na} 0 \mathrm{Cl}$. Whereas no contamination was recorded with $4.0 \%$ and $6.0 \% \mathrm{NaOCl}$. However $6.0 \% \mathrm{Na} 0 \mathrm{Cl}$ had a negative effect on seeds viability and browining the placenta and the pericarp explants. Significant diffrences were also found among the explants. 
Table 1 Effect of $\mathrm{NaOCl}$ concentration on the contamination $\%$ of chilli pepper explants.

\begin{tabular}{lllll}
\hline \multirow{2}{*}{$\mathrm{NaOCl} \%$} & \multicolumn{3}{c}{ Explants contamination (\%) } & Mean \\
\cline { 2 - 5 } & Seeds & Placenta & Pericarp & 87.0 \\
0.0 & 100 & 61.0 & 100 & 43.11 \\
2.0 & 37.67 & 20.0 & 71.67 & 0.0 \\
4.0 & 0.0 & 0.0 & 0.0 & 0.0 \\
6.0 & 0.0 & 0.0 & 0.0 & 32.53 \\
Mean & 34.42 & 20.25 & 42.92 & $\mathrm{NaOCl} \% 2.2$ \\
L.S.D.(0.05) Explant 1.9 & Interaction 3.8 & & \\
\hline
\end{tabular}

The lowest contamination was recorded for the placenta $(20.25 \%)$ compared with $(34.42 \%)$ and $(42.92 \%)$ for the seeds and the pericarps respectively. The interaction between the explant and the sterilization treatments showed that $4 \%$ and $6 \%$ $\mathrm{NaOCl}$ gave $0 \%$ contamination in all the explants under investigation. To avoid browning of the tissue $4 \% \mathrm{NaOCl}$ was adopted in the precent study.

The establishment of sterilized culture has great impact on the success of any tissue culture project. Thus several disinfectants have been used for the surface sterilization of different cultured explants. Some with high hazard such as mercuri chlorite $\left(\mathrm{HgCl}_{2}\right)$ which required special handling [13] or antibiotics [14]. In the current experiment two disinfectants were used a combination of constant concentration of Ethanol and four different concentrations of Sodium Hypochlorite. The last is widely used in tissue culture for it's affect on a wide range of microorganisms $[9,15,16] . \mathrm{HOCl}$ (hypochlorous acid) is formed during the interaction of $\mathrm{NaOCl}$ with $\mathrm{H}_{2} \mathrm{O}$ which act as oxidative and $\mathrm{Cl}$ is released [17].

\subsection{Effect of Growth Regulators on Calli Fresh Weight}

The results showed (Table 2a) significant effect for IAA concentrations on calli fresh weight. The addition of ( $2 \mathrm{mg} / \mathrm{L})$ IAA to the medium gave the highest fresh weight $(220.47 \mathrm{mg})$ compared with the other treatments. Moreover Kinetin showed the same effect as IAA. The highest fresh weight $(214.12 \mathrm{mg})$ was obtained when $(2 \mathrm{mg} / \mathrm{L})$ of Kinetin was used and it was significantly different than the other treatments.
In regard to the interaction between the growth regulators the results showed that MS medium supplemented with $(2 \mathrm{mg} / \mathrm{L})$ of each hormone gave the highest callus fresh weight $(323.0 \mathrm{mg})$ which was significantly different than the other combinations.

\subsection{Effect of Explant and Growth Regulators on Callus Induction}

The results showed significant effect for the explant on the callus fresh weight in the presence of IAA in different concentrations (Table 2b) .The Hypocotyls gave the highest fresh weight followed by Cotyledonal Leaf with a mean of $(160.58 \mathrm{mg})$ and $(147.81 \mathrm{mg})$ respectively. The lowest weight was $(122.33 \mathrm{mg})$ which was recorded for the roots. In regard to the interaction of explant and IAA, the highest fresh weight was (247.26 mg) for the Hypocotyl grown on medium supplemented with $2 \mathrm{mg} / \mathrm{L}$ IAA whereas the lowest was $(54.08 \mathrm{mg})$ for the roots grown on medium without IAA.

Moreover the results (Table 2c) showed that callus fresh weight produced from different explants is affected by the addition of Kinetin in different concentrations. The highest fresh weight was (238.35 $\mathrm{mg}$ ) for the calli produced from the Hypocotyls in the presence of $2 \mathrm{mg} / \mathrm{L}$ Kinetin and the lowest was 41.14 $\mathrm{mg}$ for the calli of the roots cultured on medium without Kinetin. without Kinetin. The interaction analysis between the Kinetin and the explants showed that calli produced from the Hypocotyls gave the highest fresh weight when $2 \mathrm{mg} / \mathrm{L}$ of Kinetin was added to the medium followed by Cotyledonal leaves $(238.35 \mathrm{mg})$ and $(223.69 \mathrm{mg})$ respectively. Three ways 
Explants of Chilli Pepper (Capsicum annuum L.)

Table 2a Effect of growth regulators on callus fresh weight (mg).

\begin{tabular}{llllll}
\hline \multirow{2}{*}{ IAA $\mathrm{mg} / \mathrm{L}$} & \multicolumn{5}{c}{ Kinetin $\mathrm{mg} / \mathrm{L}$} \\
\cline { 2 - 6 } & 0.0 & 0.5 & 1.0 & 2.0 & Mean \\
\hline 0.0 & 00.00 & 53.58 & 89.26 & 116.81 & 64.91 \\
1.0 & 45.17 & 143.97 & 163.81 & 202.54 & 138.88 \\
2.0 & 115.5 & 190.8 & 252.58 & 323.00 & 220.47 \\
Mean & 53.56 & 129.45 & 168.55 & 214.12 & IAA 1.17 \\
L.S.D. $(0.05)$ Kinetin 1.35 & Interaction 2.34 & & & \\
\hline
\end{tabular}

Table 2b The effect of explants and IAA on callus fresh weight (mg).

\begin{tabular}{llllll}
\hline \multirow{2}{*}{ IAA mg/L } & \multicolumn{5}{c}{ Explants $\mathrm{mg} / \mathrm{L}$} \\
\cline { 2 - 6 } & Shoot tips & Cotyledonal leaves & Hypocotyls & Roots & Mean \\
\hline 0.0 & 66.41 & 69.16 & 73.59 & 54.08 & 64.91 \\
1.0 & 130.74 & 144.55 & 160.87 & 119.33 & 138.88 \\
2.0 & 207.71 & 229.72 & 247.26 & 197.17 & 220.47 \\
Mean & 134.95 & 147.81 & 160.58 & 122.33 & IAA 1.17 \\
L.S.D.(0.05) & Explant 1.35 & & Interaction 2.34 & & \\
\hline
\end{tabular}

Table 2c The effect of explant and Kinetin on callus fresh weight (mg).

\begin{tabular}{llllll}
\hline \multirow{2}{*}{ Kinetin mg/L } & \multicolumn{5}{c}{ Explants $\mathrm{mg} / \mathrm{L}$} \\
\cline { 2 - 6 } & Shoot tips & Cotyledonal leaves & Hypocotyls & Roots & Mean \\
\hline 0.0 & 46.84 & 59.31 & 66.93 & 41.14 & 53.56 \\
0.5 & 125.77 & 130.65 & 145.76 & 115.62 & 129.45 \\
1.0 & 160.92 & 177.59 & 191.26 & 144.43 & 168.55 \\
2.0 & 206.29 & 223.69 & 238.35 & 188.13 & 214.12 \\
Mean & 134.95 & 147.81 & 160.58 & 122.33 & Kinetin 1.35 \\
L.S.D.(0.05) & Explant 1.35 & \multicolumn{2}{c}{ Interaction 2.70 } \\
\hline
\end{tabular}

Table 2d The effect of explants, IAA and Kinetin on callus fresh weight (mg).

\begin{tabular}{|c|c|c|c|c|c|}
\hline \multirow{2}{*}{ IAA mg/L } & \multirow{2}{*}{ Kinetin } & \multicolumn{4}{|c|}{ Explants $\mathrm{mg} / \mathrm{L}$} \\
\hline & & Shoot tips & Cotyledonal leaves & Hypocotyls & Roots \\
\hline \multirow{4}{*}{0.0} & 0.0 & 0.0 & 0.0 & 0.0 & 0.0 \\
\hline & 0.5 & 68.90 & 53.18 & 55.06 & 37.18 \\
\hline & 1.0 & 81.44 & 102.54 & 111.92 & 61.14 \\
\hline & 2.0 & 115.30 & 120.94 & 127.38 & 103.61 \\
\hline \multirow{4}{*}{1.0} & 0.0 & 35.11 & 48.53 & 64.46 & 32.60 \\
\hline & 0.5 & 137.68 & 145.90 & 164.02 & 128.28 \\
\hline & 1.0 & 156.36 & 172.76 & 185.82 & 140.31 \\
\hline & 2.0 & 193.82 & 211.00 & 229.20 & 176.14 \\
\hline \multirow{4}{*}{2.0} & 0.0 & 105.42 & 129.40 & 136.34 & 90.82 \\
\hline & 0.5 & 170.72 & 192.88 & 218.20 & 181.40 \\
\hline & 1.0 & 244.96 & 257.46 & 276.04 & 231.84 \\
\hline & 2.0 & 309.74 & 339.14 & 358.48 & 284.64 \\
\hline
\end{tabular}


interactions (Table 2d) among IAA and Kinetin concentrations and the explants showed significant effect on callus fresh weight. No callus was produced from any explants from the treatment without growth regulators. However, small amount of calli were produced from all the explants when IAA or Kinetin alone is added to the medium. On the other hand, the treatment $2 \mathrm{mg} / \mathrm{L}$ of both IAA and Kinetin surpass all other treatments by giving the highest fresh weight of calli from all explants.

Pericarp and Placenta did not induce calli on the media supplemented with IAA and Kinetin in all combinations and concentrations therefore NAA or 2,4-D were used. The results (Table 3) showed significant effect for NAA on calli fresh weight induced from these explants. No calli were induced from both explants without NAA, whereas the Pericarps gave significantly higher fresh weight than the Placenta with a mean of $125.77 \mathrm{mg}$ and $110.42 \mathrm{mg}$ respectively. The medium with $2 \mathrm{mg} / \mathrm{L}$ NAA gave the highest fresh weight $(197.60 \mathrm{mg})$ which was significantly different from the other treatments. Moreover the interaction analysis showed that the Pericarps gave the highest fresh weight $(210.30 \mathrm{mg})$ when they were cultured on medium supplemented with $2 \mathrm{mg} / \mathrm{L}$ NAA. But it was not significantly different from $(184.90 \mathrm{mg})$ for the placenta cultured on the same medium. However both of them were significantly higher than the other combinations.

The addition of 2,4-D to the callus induction medium showed significant effect on callus fresh weight of all explants whereas no callus was induced without 2,4-D (Table 4). The highest fresh weight (265.25 mg) was obtained when $2 \mathrm{mg} / \mathrm{L} \mathrm{2,4-D} \mathrm{was}$ added to the medium which was significantly different than the other concentrations. The explant type showed low significant difference in the fresh weight with the pericarp $(173.85 \mathrm{mg})$ higher than the placenta $(154.90 \mathrm{mg})$. The interaction analysis showed that the lowest fresh weight was $(155.30 \mathrm{mg})$ which was recorded for the calli induced from the Placenta on medium supplemented with $1 \mathrm{mg} / \mathrm{L}$ 2,4-D. Moreover no significant differences in the average callus fresh weight for calli induced from the pericarp on media supplemented with 2 or $4 \mathrm{mg} / \mathrm{L}$ 2,4-D and from the placenta grown on media supplemented with $2 \mathrm{mg} / \mathrm{L}$ 2,4-D, but they were significantly different than the other treatments.

Table 3 Effect of NAA concentrations on callus fresh weight (mg) from different explants of chilli pepper.

\begin{tabular}{|c|c|c|c|}
\hline \multirow{2}{*}{ NAA mg/L } & \multicolumn{2}{|c|}{ Explant mg/L } & \multirow{2}{*}{-Mean } \\
\hline & Pericarp & Placenta & \\
\hline 0.0 & 0.0 & 0.0 & 0.0 \\
\hline 1.0 & 133.60 & 115.30 & 124.45 \\
\hline 2.0 & 210.30 & 184.90 & 197.60 \\
\hline 4.0 & 159.20 & 141.50 & 150.35 \\
\hline Mean & 125.77 & 110.42 & \\
\hline L.S.D.(0.05) Explant 10.4 & \multicolumn{2}{|c|}{ Interaction $31.2 \mathrm{NAA}$} & Concentrations 16.7 \\
\hline
\end{tabular}

Table 4 Effect of 2,4-D concentrations on callus fresh weight ( $\mathrm{mg})$ induced from different explants of chilli pepper.

\begin{tabular}{llll}
\hline $2,4-\mathrm{D}$ & \multicolumn{2}{c}{ Explant $\mathrm{mg} / \mathrm{L}$} & Mean \\
\cline { 2 - 4 } $\mathrm{mg} / \mathrm{L}$ & Pericarp & Placenta & 0.0 \\
\hline 0.0 & 0.0 & 0.0 & 159.85 \\
1.0 & 164.40 & 155.30 & 265.25 \\
2.0 & 276.90 & 253.60 & 232.40 \\
4.0 & 254.10 & 210.70 & \\
Mean & 173.85 & 154.90 & Concentrations 18.1 \\
L.S.D.(0.05) & Explant 13.2 & \multicolumn{2}{c}{ Interaction 33.04 2,4-D } \\
\hline
\end{tabular}




\section{Discussion}

The current experiment showed that all the explants of the chilli pepper plant did not induce callus on the medium without growth regulators. The presences of Auxins in the medium affect cell elongation by altering cell wall plasticity and have positive influence on cell enlargement. However, high concentrations of the Auxins are toxic to the plant cells. These facts explain the increase in the callus fresh weight as the concentration of the Auxins increased up to a specific level. High concentration of 2,4-D and NAA (naphthalene acetic acid) (4 mg/L) gave less fresh weight than $2 \mathrm{mg} / \mathrm{L}$ of both. The callus was watery and non regenarable type (Fig. 1). This might be due to Ethylene production which reduces cell division [25]. Moreover high concentrations had negative effect on the enzymes responsible for cell wall structure and mechanism hence affecting cell division [19]. Synthetic auxin like 2,4-D has been developed as herbicide to control weed. On the other hand low concentration of 2,4-D reduces RNA polymerase activity which reduces cell division [20]. Low and high concentration of 2,4-D reduces the enzyme activity for nucleotide incorporation in RNA which is required for continued tissue growth [21].

The suitable 2,4-D concentration increases DNA and RNA which enhances growth [22]. Hasanat [9] showed that the suitable Auxin concentration in the medium will affect expansion enzyme and loosening the cell wall which inhibit initial growth of the explant. Callus induction depends greatly on the balance of Auxins and Cytokinins in the cells. The last plays important role in the cell division due to its adenine group [23]. Taiz and Zeiger [19] reported that the optimal Auxin concentration increased rRNA transcription and propagation and enzyme activity which will accelerate callus growth.

The addition of Auxins and Cytokinins in the medium induces lateral bud formation. Several researchers found that this combination initiate shoot formation on pepper hypocotyls [24, 25]. On the contrary the results of the current experiment agreed with what was reported by Christopher and Rajam [26] that the endogenous Cytokinins of Capsicum are very high thus the explants induce calli instead of lateral buds.

Callus was induced from all explants on all types of medium used in this experiment (Fig. 2). Although the medium with $1 \mathrm{mg} / \mathrm{L}$ IAA and $0.5 \mathrm{mg} / \mathrm{L}$ Kinetin gave the highest calli fresh weight was not adopted for further experiment because the explants produced calli and formed shoots as well (Fig. 3). However, the medium which was supplemented with $2 \mathrm{mg} / \mathrm{L}$ of both IAA and Kinetin that induced callus only without shoot formation was the best. Moreover the best explant for callus induction under the conditions of the current experiment is the Hypocotyls. This result is in

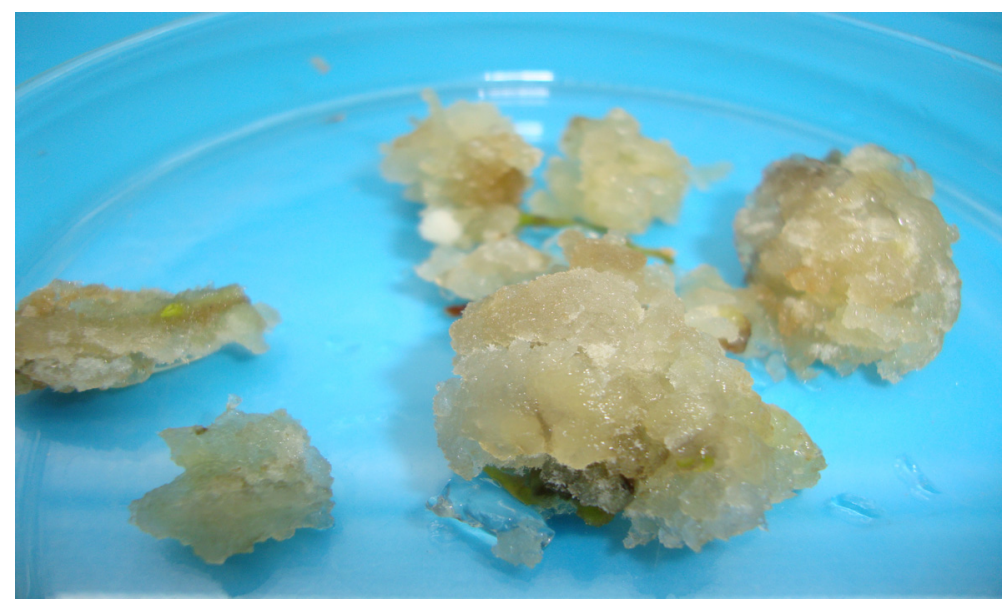

Fig. 1 Watery and non regenerable callus type. 

Explants of Chilli Pepper (Capsicum annuum L.)
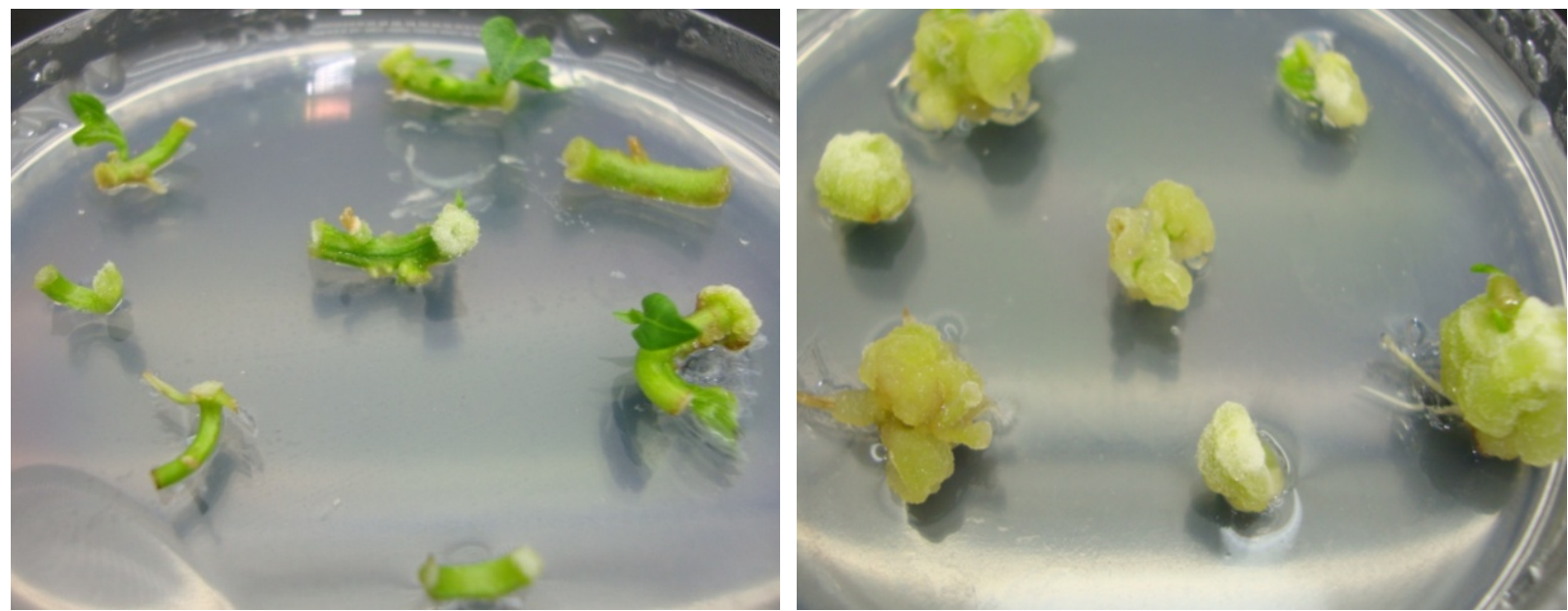

(a)

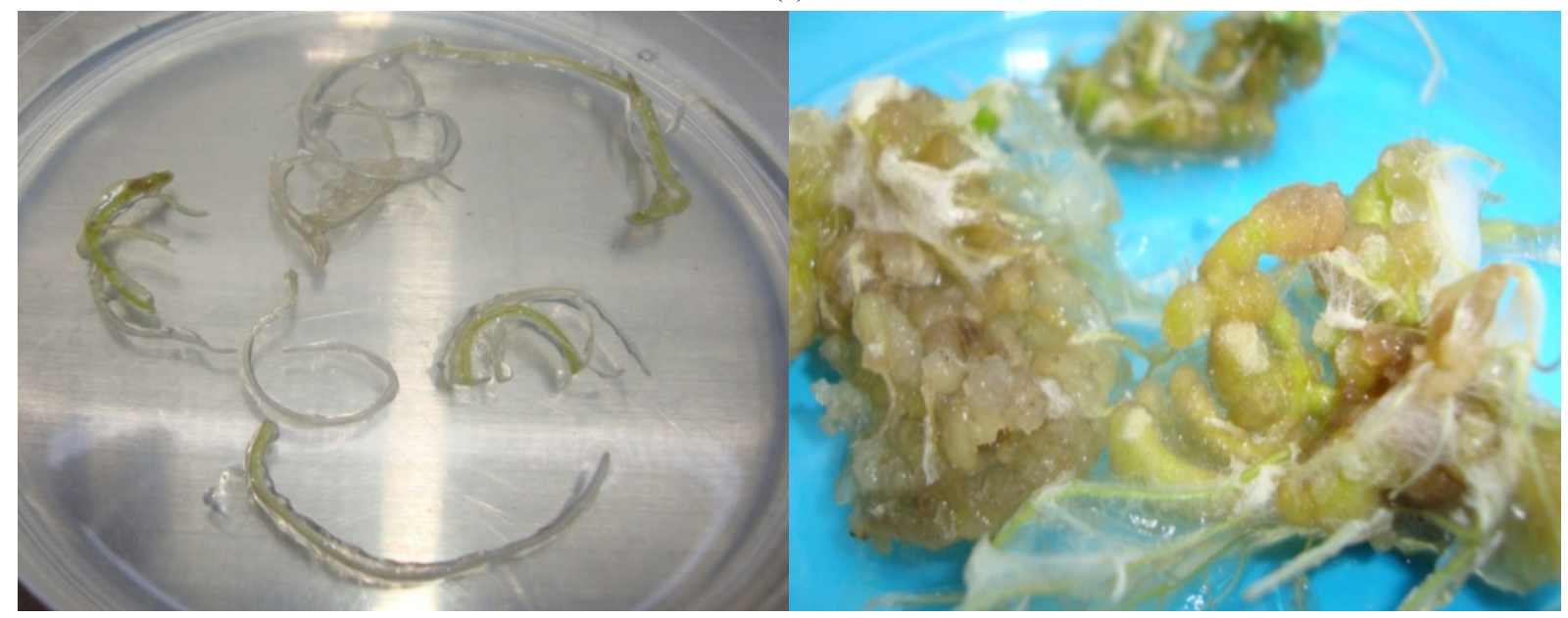

(b)

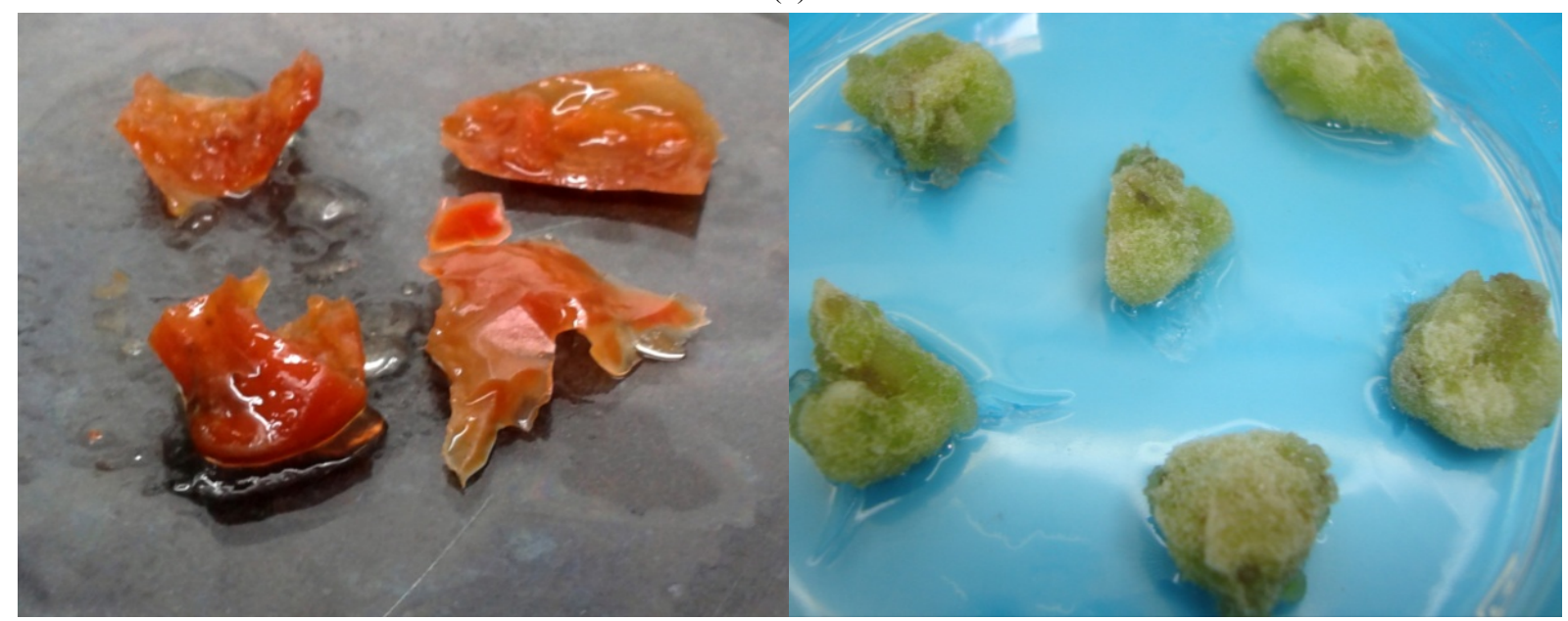

(c)

Fig. 2 The explants and the calli produced from them: a: Hypocotyl; b: Root; c: Pericarp. 


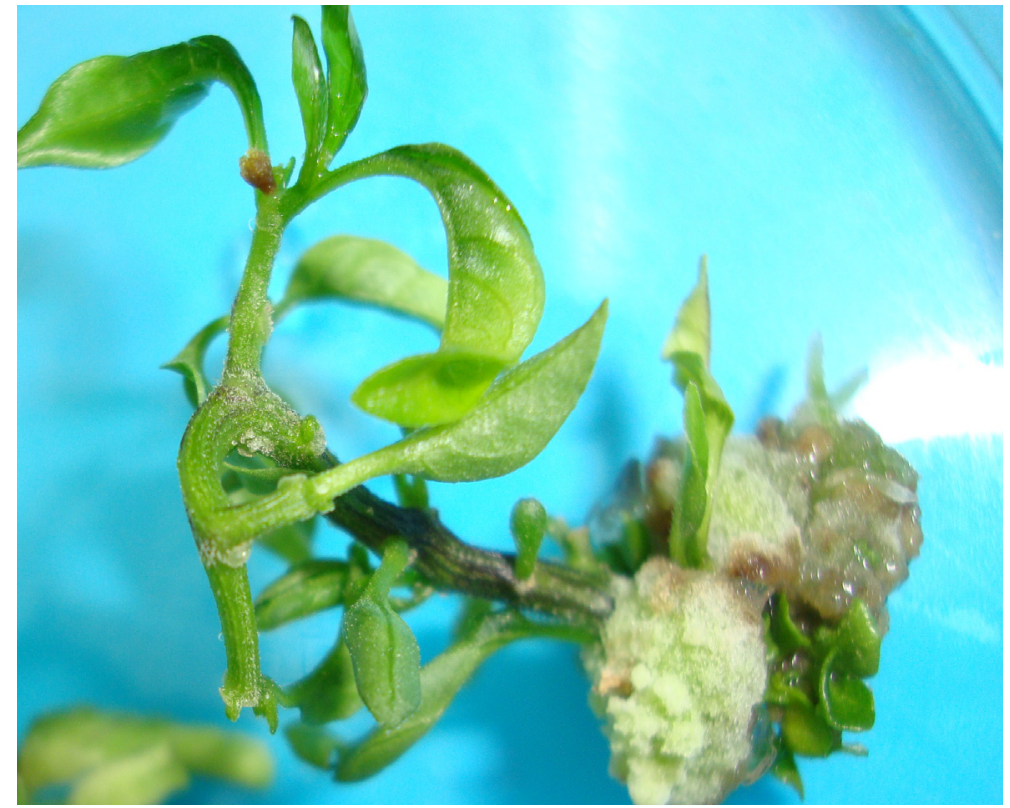

Fig. 3 Calli and shoots produced on medium supplemented with1 mg/L IAA and $0.5 \mathrm{mg} / \mathrm{L}$ Kinetin.

agreement with what was found by Umamaheswari and Lalitha [21]. The different response of the explants is due to the endogenous hormones which control cell division and callus growth.

\section{Conclusions}

In conclusion the best sterilization method of chilli pepper seeds is by $70 \%$ ethanol for one minute followed by $20 \mathrm{~min}$ in $4 \%(\mathrm{NaOCl})$. The best explants for callus induction only is the Hypocotyls grown on MS medium supplemented with $2 \mathrm{mg} / \mathrm{L}$ of IAA and Kinetin under the conditions of the current experiment.

\section{References}

[1] Kumar, S., Kumar, R., and Singh, J. 2006. "Cayenne/American Pepper (Capsicum Species)." In: Handbook of Herbs and Spices, edited by Peter, K.V. Cambridge: Woodhead Publishing.

[2] Sanatombi, K., and Sharma, G. J. 2007. "Micropropagation of Capsicum annuum L." Not. Bot. Hort. Agrobot. Cluj. 35.

[3] Arora, R., Gill, N. S., Chauhan, G., and Rana, A. C. 2011. "An Overview about Versatile Molecule Capsaicin." International Journal of Pharmaceutical Sciences and Drug Research 3 (4): 280-286.

[4] Kothari, S. L., Joshi, A., Kachhwaha, S., and Ochoa-Alejo, N. 2010. "Chilli Peppers-A Review on Tissue Culture and Transgenesis." Biotechnology
Advances 28: 35-48.

[5] Berljak, J. 1999. "In vitro Plant Regeneration from Pepper (Capsicum annuum L. cv. Soroksari) Seedling Explant." Phyton (Austria) Special issue: Plant Physiology 39 (3): 289-292.

[6] Ramawat, K. G. 2004. Plant Biotechnology.

[7] Sadhineni, M., and Patil, V. C. 2007. "Yield Estimation in Chilli (Capsicum annuum L.) Using Remote Sensing." J. Res. Angrav 35 (3): 1-11.

[8] Aza-Gonzalez, C., Hector, G., Palenius, N., and Ochoa-Aleja, N. 2011. "Molecular Biology of Capsaicinoid Biosynthesis in Chilli Pepper (Capsicum spp.)." Plant Cell Rep 30: 695-706.

[9] Hasnat, R., Abbasi, N. A., Ahmad, T., and Hafiz, I. A. 2007. "Induction and Regeneration of Hypocotyls Derived Calli in Chilli Chilli (Capsicum frutescens L.)" Pak. J. Bot. 39 (5): 1787-1795.

[10] Ngai, P. H., and Ng, T. B. 2006. "A Lectin with Antifungal and Mitogenic Activities from Red Cluster Pepper (Capsicum frutescens) Seeds." Appl. Microbiol. Biotech. 74 (2): 366-371.

[11] Glaser, A., and Biggs, C. 2010. An Introduction to Statistical Methods in GenStat.

[12] Prakash, A. H., Sankara, R. K., and Kumar, M. 1997. "Plant Regeneration from Protoplasts of Capsicum annuum L. cv. California Wonder.” J. Biosci 22 (3): 339-344.

[13] Ahloowalia, B. S., Prekash, J., Savangikar, V. A., and Savangikar, C. 2004. Plant tissue culture. In: Proceedings of a Technical Meeting organized by the Joint FAO/IAEA Division of Nuclear Techniques in Food and Agriculture. August 26-30, 2002, IAEA, Vienna. 
[14] Jerico, J. B., Adriana, F., Eduardo, B-Uc, Eunice, G-Uc, and Manuel, L. R. 2010. "Improvement of In Vitro Proliferation and Elongation of Habanero Pepper Shoots (Capsicum chinense Jacq.) by Temporary Immersion. “Hortscience 45 (7):1093-1098.

[15] Trigiano, R. N., and Gray, D. J. 2000. Plant Tissue culture concepts and Laboratory Exercises. CRC Press LLC.

[16] Gudeva, L. K., and Veselinovska, S. S. 2011. Some Physiological Characteristics of Pepper (Capsicum annuum L.) Produced in vitro. J. of Biology, 7 (1): 1-5.

[17] Rodeva, V. N., Irikova, T. P., and Todorova, V. J. 2004. "Anther Culture of Pepper (Capsicum annuum L.) : Comparative Study on Effect of the Genotype." Biotechnol and Biotechnol Eq. 18 (3): 34-38.

[18] Taiz, L., and Zeiger, E. 2002. Planta Physiology, Sinauer Assciates. Massachusetts: Sunderland.

[19] Umamaheswari, A., and Lalitha, V. 2007. "In vitro Effect of Various Growth Hormones in Capsicum annuum L. on the Callus Induction and Production of Capsaicin." $J$. Plant Sci. 2: 545-551.

[20] Gandonou, Ch., Errabi, T., Abrini, J., Idaomar, M., Chibi, F., and Senhaji, S. 2005. "Effect of Genotype on Callus Induction and Plant Regeneration from Leaf Explants of
Sugarcane (Saccharum sp.)." Afr. J. Biotech. 4 (11): 1250-1255.

[21] Salisbury, F. B., and Ross, C. W. 2005. "Hormones and Growth Regulators: Auxin and Gibberellins." In Plant Physiology. Singapore: Thomson Asia Ptv. Ltd.

[22] Murashige, T., and Skoog, F. 1962. "A Revised Medium for Rapid Growth and Bio Assays with Tobacco Tissue Cultures." Physiol. Pl. 15: 473-497.

[23] Goodwin, M. 1985. Introduction to Plant Biochemistry. New York: Pergamon Press..

[24] Gunay, A. L., and Rao, P. S. 1978. "In vitro Plant Regeneration from Hypocotyls and Cotyledon Explants of Red Pepper (Capsicum annuum L.)" Plan Sci. Lett. 11: 365-372.

[25] Stoica, R., Mihaela, S., Guidea, D., Iordanescu, I., and Babeanu, N. 2014. "In vitro Approaches on the Development and Proliferative Growth of Induction Callus from Somatic Explants of Chilli Chilli Pepper ( $C$. annuum. L. CV. Pintea and the CV. DE Cayenne)." Scientific Bulletin. Series F. Biotechnologies.

[26] Christopher, T., and Rajam, M. V. 1996. "Effect of Genotype Explant and Medium on in vitro Regeneration of Red Pepper." Plant Cell Tissu Organ Cult 46 (3): 245-250. 